УДК 504.054:614.843.8

Sergii S. Poroshenko, student

e-mail: ldubzh.lviv@dsns.gov.ua

Lviv State University of Life Safety, Lviv, Ukraine

\title{
THE ANALYSIS OF METHODS OF INVESTIGATION OF NEGATIVE IMPACT ON MESOFAUNA AND MICROBIOLOGY OF SOILS OF CONTAMINATED SOLUTIONS FOR FOAM MAKERS
}

\begin{abstract}
Nowdays the problem of fires is becoming more widespread and global in scale. According to statistics published by the Ukrainian Research Institute of Civil Protection obtained as a result of analysis of the fire registration cards of the SES of Ukraine - for 11 months of 2019 the number of fires in Ukraine increased by $23.1 \%$ compared to the same period last year. The most common extinguishing agent being used by fire and rescue units today is a foam. The main component of different foaming agents are surfactants. Their excessive emission into the environment leads to pollution of the surrounding areas. The constant increasing of the land areas affected by the effects of firefighting influence both the state of the environment in the region as a whole and the level of soil fertility. Microbiological indicators and the content of harmful substances in crops are increasing and thus the negative impact on public health grows. The analysis of microbiological monitoring methods with the aim of the contaminated solutions foam makers impact on the nearby territories' soils estimation has been carried out. The pros and cons of modern physical and chemical methods of soils quality estimation have been defined. The necessity of microbiological methods usage which allow to get full and sufficient information not only about the pollution volume, but also to rate the results of such pollution has been justified. It is determined that in order to obtain the most complete and objective information about the microbiological condition of soils contaminated with foaming agents for fire extinguishing, a complex of bioindication methods should be used. It should include a growth test and a chromosome aberration test, with the use of test organisms that are most sensitive to the chemical composition of the test solution for firefighting.
\end{abstract}

Key words: foaming solutions; surfactants; environmental assessment; microbiological of soils monitoring; phytotoxicity

\section{С.С. Порошенко}

Львівський державний університет безпеки життєдіяльності, Львів, Україна

\section{АНАЛІЗ МЕТОДІВ ДОСЛІДЖЕННЯ НЕГАТИВНОГО ВПЛИВУ НА МЕЗОФАУНУ ТА МІКРОБІОЛОГІЮ ГРУНТІВ, ЗАБРУДНЕНИХ РОЗЧИНАМИ ПІНОУТВОРЮВАЧІВ ДЛЯ ГАСІННЯ ПОЖЕЖ}

\begin{abstract}
Анотація. На сьогоднішній день проблема виникнення пожеж стає все більш поширеною та глобальною за своїми масштабами. Відповідно до оприлюднених Українським науково-дослідним інститутом иивільного захисту статистичних даних, отриманих в результаті проведення аналізу масиву карток обліку пожеж ДСНС Украӥни, за 11 місяців 2019 року кількість пожеж в Украӥні зросла на 23.1\% порівняно з аналогічним періодом попереднього року.
\end{abstract}

(C) С.С. Порошенко, 2020

ISSN: 2411-4049. Екологічна безпека та природокористування, № 2 (34), 2020 
Найпоширенішою вогнегасною речовиною у використанні пожежнорятувальних підрозділів на сьогоднішній день залишається піна. Головним компонентом піноутворювачів різних категорій $\epsilon$ поверхнево-активні речовини, потрапляння яких у надмірних концентраціях в навколишнє середовище призводить до забруднення прилеглих територій. Постійне збільшення площ земель, уражених наслідками пожежогасіння, впливає як на стан навколишнього середовища регіону загалом, так $i$ на рівень родючості трунтів. Збільшуються мікробіологічні показники та вміст шкідливих речовин в сільськогосподарських культурах, а відтак і негативний вплив на здоров'я населення. На даному етапі спостереження $і$ контроль за станом трунтів проводиться, як правило, лише за допомогою фізикохімічних аналізів, які визначають вміст окремих забруднювачів. Однак иі аналізи не дають змогу оцінити вплив забруднювачів на живі організми, в тому числі людину. На сьогодні альтернативними при дослідженні стану трунтів, уражених пожежними піноутворювачами, $\epsilon$ методи мікробіологічного моніторингу. Проведено аналіз методів мікробіологічного моніторингу з метою очінки впливу розчинів піноутворювачів для гасіння пожеж на стан трунтів прилеглих територій. Визначено переваги та недоліки сучасних фізико-хімічних методів очінки якості трунтів. Обтрунтовано необхідність застосування методів мікробіологічного моніторингу, які дають змогу отримати повну та достатню інформацію не лише про об'єми забруднення, а й оиінити результати впливу такого забруднення. Визначено, що для отримання найбільш повної та об'єктивної інформації про мікробіологічний стан трунтів, забруднених розчинами піноутворювачів для гасіння пожеж, слід застосовувати комплекс біоіндикаційних методів оцінки шкідливості, який повинен включати ростовий тест та тест "Аберантність хромосом», при иььму обов'язковим $\epsilon$ використання комплексу тест-організмів, найбільи чутливих до хімічного складу досліджуваного розчину для пожежогасіння.

Ключові слова: розчини піноутворювачів; поверхнево-активні речовини; екологічна оцінка; мікробіологічний моніторинг трунтів; фітотоксичність

\section{Постановка проблеми}

На сьогоднішній день проблема виникнення пожеж стає все більш поширеною та глобальною за своїми масштабами. Відповідно до оприлюднених Українським науково-дослідним інститутом цивільного захисту статистичних даних, отриманих в результаті проведення аналізу масиву карток обліку пожеж ДСНС України, за 11 місяців 2019 року кількість пожеж в Україні зросла на $23.1 \%$ порівняно 3 аналогічним періодом попереднього року [1]. Найбільш ефективним способом локалізації та гасіння пожеж на початкових стадіях визнано метод ізоляції, при якому застосовуються різноманітні вогнегасні речовини ізолюючої дії. Найпоширенішою вогнегасною речовиною у використанні пожежно-рятувальних підрозділів на сьогоднішній день залишається піна [2].

Розчином піноутворювача для гасіння пожеж називають речовину, що в результаті змішування з водою утворює певний робочий розчин, який генерує піну, та змочувальний розчин. Головним компонентом піноутворювачів різних категорій $є$ поверхнево-активні речовини (ПАР), потрапляння яких у надмірних концентраціях в навколишнє середовище призводить до забруднення прилеглих територій [3]. 
Особливої уваги потребує все ж проблема забруднення грунтів піноутворювальними засобами гасіння пожеж, оскільки постійне збільшення площ земель, уражених наслідками пожежогасіння, впливає як на стан навколишнього середовища регіону загалом, так і на рівень родючості грунтів, їх мікробіологічні показники та вміст шкідливих речовин в сільськогосподарських культурах, що вирощуються на них, а відтак і на здоров'я населення.

\section{Аналіз останніх досліджень та публікацій}

Питанням визначення оцінки забруднення грунтів антропогенними забрудниками займалось багато провідних вчених, серед них Васенко О.Г., Рибалова О.В., Артем'єв С.P., Горбань Н.С., Козловська О.В., Горова А.I, Губачов О.І., Маячкіна Н.В., Чугунова М.В. та інші.

Проте слід зазначити, що в сучасній літературі немає універсального методу, який би визначав екологічний стан грунтів, забруднених наслідками пожежогасіння, i тому питання дослідження екологічної безпеки даних територій потребують подальших наукових розробок.

\section{Виділення невирішених раніше частин проблеми}

На даному етапі спостереження і контроль за станом грунтів проводиться, як правило, лише за допомогою фізико-хімічних аналізів, які визначають вміст окремих забруднювачів. Переваги та недоліки основних сучасних фізикохімічних методів оцінки якості грунтів наведено в табл. 1.

Таблиця 1 - Переваги та недоліки сучасних фізико-хімічних методів оцінки якості грунтів

\begin{tabular}{|c|c|c|}
\hline Назва методу & Переваги & Недоліки \\
\hline $\begin{array}{l}\text { Гравіметричний } \\
\text { метод }\end{array}$ & \begin{tabular}{lc}
\multicolumn{2}{l}{ Висока точність; } \\
Абсолютний & метод, не \\
потребуючий & \multicolumn{2}{c}{ порівняння } \\
$\begin{array}{l}\text { отриманого } \\
\text { еталонами. }\end{array}$ & результату 3 \\
&
\end{tabular} & $\begin{array}{l}\text { Довготривалість дослідження; } \\
\text { Можливість визначення лише } \\
\text { деяких хімічних компонентів. }\end{array}$ \\
\hline $\begin{array}{l}\text { Потенціометричний } \\
\text { метод }\end{array}$ & $\begin{array}{l}\text { Можливість проведення } \\
\text { аналізу в польових умовах; } \\
\text { Метод є недеструктивним, } \\
\text { тобто аналізуюча проба в ході } \\
\text { аналізу не витрачається і не } \\
\text { змінює свої властивості; } \\
\text { Висока відтворюваність } \\
\text { методу. }\end{array}$ & $\begin{array}{l}\text { - Довготривалість дослідження, } \\
\text { включаючи складну підготовку } \\
\text { проб грунту; } \\
\text { Можливість визначення лише } \\
\text { деяких хімічних компонентів; } \\
\text { Потреба у кваліфікованих } \\
\text { спеціалістах; } \\
\text { - Високі матеріальні затрати. }\end{array}$ \\
\hline Оптичний метод & $\begin{array}{l}\text { Висока точність; } \\
\text { Висока } \\
\text { методу. }\end{array}$ & $\begin{array}{l}\text { - Довготривалість дослідження, } \\
\text { включаючи складну підготовку } \\
\text { проб грунту; } \\
\text { Можливість дослідження вмісту } \\
\text { лише попередньо визначених } \\
\text { хімічних компонентів; } \\
\text { Потреба у висококваліфікованих } \\
\text { спеціалістах. }\end{array}$ \\
\hline
\end{tabular}


Продовження таблиці 1

\begin{tabular}{|c|c|c|}
\hline Назва методу & Переваги & Недоліки \\
\hline $\begin{array}{l}\text { Молекулярно- } \\
\text { абсорбційна } \\
\text { спектроскопія }\end{array}$ & $\begin{array}{l}\text { Висока точність; } \\
\text { Висока } \\
\text { методу. }\end{array}$ & $\begin{array}{l}\text { Високі матеріальні затрати; } \\
\text { Довготривалість дослідження; } \\
\text { Можливість дослідження вмісту } \\
\text { лише попередньо визначених } \\
\text { хімічних компонентів; } \\
\text { Потреба у висококваліфікованих } \\
\text { спеціалістах; } \\
\text { Потреба великої кількості } \\
\text { хімічних реактивів. }\end{array}$ \\
\hline $\begin{array}{l}\text { Полум'яно-емісійна } \\
\text { спектрометрія }\end{array}$ & $\begin{array}{l}\text { Прості та дешеві прилади; } \\
\text { Висока чутливість визначення } \\
\text { лужних елементів. }\end{array}$ & 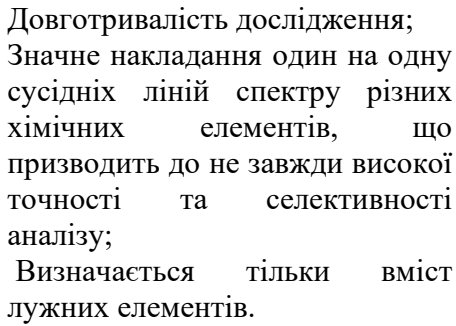 \\
\hline
\end{tabular}

Джерела: [4-6]

Однак ці аналізи не дають змогу оцінити вплив забруднювачів на живі організми, в тому числі людину [7]. Сьогодні альтернативними при дослідженні стану грунтів, уражених пожежними піноутворювачами, $є$ методи мікробіологічного моніторингу.

Мета роботи - проведення аналізу методів мікробіологічного моніторингу 3 метою оцінки впливу розчинів піноутворювачів на мезофауну та мікробіологію уражених грунтів.

\section{Виклад основного матеріалу}

Методи мікробіологічної оцінки здатні давати достовірну інформацію про якість грунтів досліджуваних територій. Суть таких методів полягає у визначенні впливу дослідних речовин на спеціально обрані тест-організми в природних умовах 3 фіксацією різних тест-реакцій (поведінкових, фізіологічних чи біохімічних). Тест-реакцію, або тест-функцію, визначають як закономірно виникаючу реакцію відповіді тест-системи на дію комплексу зовнішніх факторів [8, 9].

Наявні в розчинах піноутворювачів для пожежогасіння ПАР можуть здійснювати істотний вплив на рослинні клітини, їх фізіолого-біохімічні процеси, хімічний склад, що може призвести до зниження продуктивності та порушення мікробіологічного стану грунтів [10-12].

Мікробіота грунтів - це складна відкрита біологічна система з ієрархічною структурою організації. Для кожного ієрархічного рівня існують чутливі біодіагностичні показники. Існує декілька різних методик проведення мікробіологічної оцінки грунтів. Кожна 3 цих методик має свої переваги, недоліки та обмеження (табл. 2). 

дослідження грунтів

\begin{tabular}{|c|c|c|c|c|}
\hline $\begin{array}{l}\text { Назва } \\
\text { методу }\end{array}$ & $\begin{array}{c}\text { Ієрархі- } \\
\text { чний } \\
\text { рівень }\end{array}$ & Опис методу & Переваги & Недоліки \\
\hline 1 & 2 & 3 & 4 & 5 \\
\hline $\begin{array}{l}\text { Ростовий тест } \\
\text { (методика } \\
\text { Берес- } \\
\text { тецького О.А.) }\end{array}$ & \begin{tabular}{|l|} 
Популя- \\
ційний
\end{tabular} & 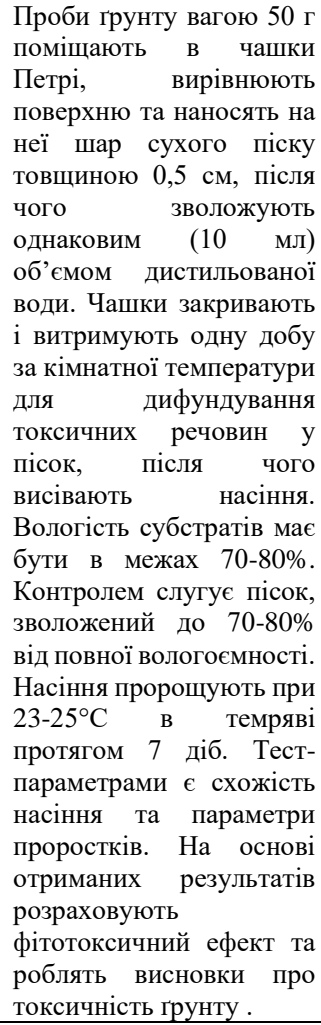 & $\begin{array}{l}\text { - Можливість оцінити } \\
\text { реакцію живих організмів } \\
\text { на присутні полютанти; } \\
\text { Доступність проведення } \\
\text { експериментів (не } \\
\text { потрібні спеціальні } \\
\text { лабораторії і висока } \\
\text { кваліфікація персоналу); } \\
\text { - Невеликі затрати праці; } \\
\text { Відносна дешевизна. }\end{array}$ & $\begin{array}{l}\text { • Необхідність великої } \\
\text { кількості повторювань } \\
\text { для розрахунку більш } \\
\text { точного фітотоксич- } \\
\text { ного ефекту; } \\
\text { • Досліджується рівень } \\
\text { організації } \\
\text { організмів, що має } \\
\text { відносно невисоку } \\
\text { чутливість і точність, } \\
\text { порівняно } \\
\text { дослідженнями на } \\
\text { клітинному рівні. }\end{array}$ \\
\hline $\begin{array}{l}\text { Ростовий тест } \\
\text { (методика } \\
\text { Горової А.І.) }\end{array}$ & \begin{tabular}{|l|} 
Популя- \\
ційний
\end{tabular} & 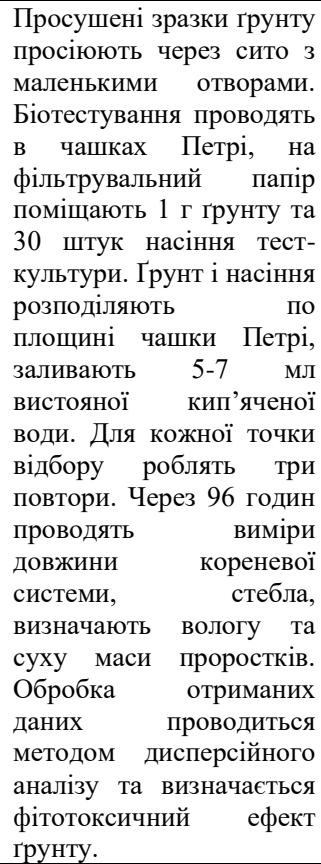 & $\begin{array}{l}\text { - Можливість оцінити } \\
\text { реакцію живих організмів } \\
\text { на присутні полютанти; } \\
\text { - Доступність проведення } \\
\text { експериментів } \text { (не } \\
\text { потрібні спеціальні } \\
\text { лабораторії і висока } \\
\text { кваліфікація персоналу); } \\
\text { - Невеликі затрати праці; } \\
\text { - Відносна дешевизна. }\end{array}$ & $\begin{array}{l}\text { - Необхідність великої } \\
\text { кількості повторювань } \\
\text { для розрахунку більш } \\
\text { точного фітотоксич- } \\
\text { ного ефекту; } \\
\text { - Досліджується рівень } \\
\text { організації } \\
\text { організмів, що має } \\
\text { відносно невисоку } \\
\text { чутливість і точність, } \\
\text { порівняно } \\
\text { дослідженнями на } \\
\text { клітинному рівні. }\end{array}$ \\
\hline
\end{tabular}


Продовження таблиці 2

\begin{tabular}{|c|c|c|c|c|}
\hline 1 & 2 & 3 & 4 & 5 \\
\hline $\begin{array}{l}\text { Оцінка стану } \\
\text { грунтів за } \\
\text { зміною } \\
\text { видового } \\
\text { біорізнома- } \\
\text { ніття } \\
\text { безхребетних } \\
\text { тварин }\end{array}$ & \begin{tabular}{|l|} 
Популя- \\
ційний
\end{tabular} & 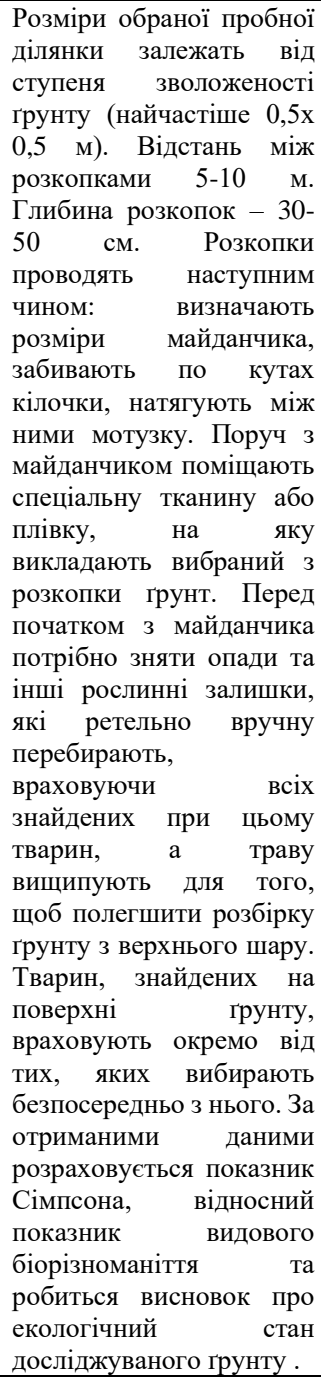 & $\begin{array}{l}\text { - Матеріальна } \\
\text { економічність; } \\
\text { - Доступність } \\
\text { проведення } \\
\text { експериментів. }\end{array}$ & $\begin{array}{llr}\text { - Висока } & \text { трудоємкість, } \\
\text { використання } & \text { методу } \\
\text { призводить } & \text { до } \\
\text { порушення } & \text { грунтового } \\
\text { покриву; } & \\
\text { • Недоцільно для вивчення } \\
\text { сезонного } & \text { коливання } \\
\text { складу } & \text { грунтової } \\
\text { мезофауни; } & \\
\text { При розкопках } & \text { рухливі } \\
\text { види фауни реагують на } \\
\text { порушення та швидко } \\
\text { зникають в інше місце } \\
\text { (збільшення } & \text { помилки } \\
\text { результатів } & \\
\text { дослідження). }\end{array}$ \\
\hline $\begin{array}{l}\text { Токсичність } \\
\text { водних } \\
\text { витяжок } \\
\text { грунтів }\end{array}$ & $\begin{array}{l}\text { Популя- } \\
\text { ційний }\end{array}$ & 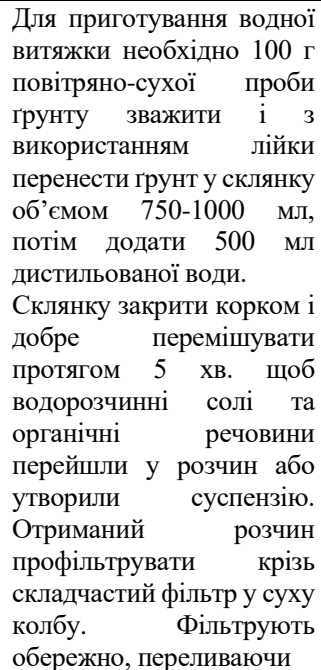 & \begin{tabular}{|lr} 
Дистильована вода, \\
по суті, імітує дію на \\
грунт атмосферних \\
опадів, отже, певною \\
мірою відтворюється \\
природна ситуація; \\
- Метод & можна \\
застосовувати & на \\
будь-яких грунтах і \\
не r \\
спеціальної \\
підготовки грунту; \\
- Водну & витяжку \\
можна & отримати \\
навіть & г грунтів, що \\
мають & польову \\
вологість.
\end{tabular} & 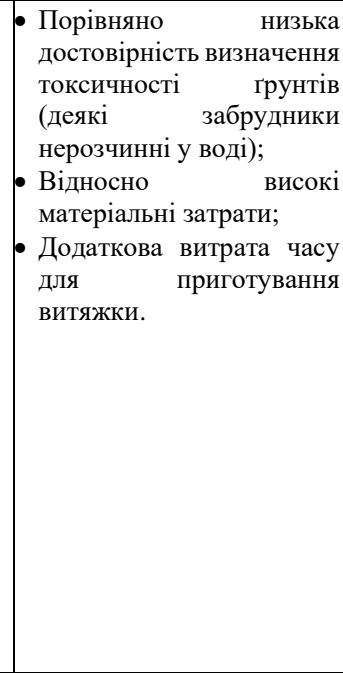 \\
\hline
\end{tabular}


Продовження таблиці 2

\begin{tabular}{|c|c|c|c|c|}
\hline 1 & 2 & 3 & 4 & 5 \\
\hline & &  & & \\
\hline $\begin{array}{l}\text { Тест } \\
\text { «Аберантність } \\
\text { хромосом» }\end{array}$ & $\begin{array}{l}\text { Клітин- } \\
\text { ний }\end{array}$ & 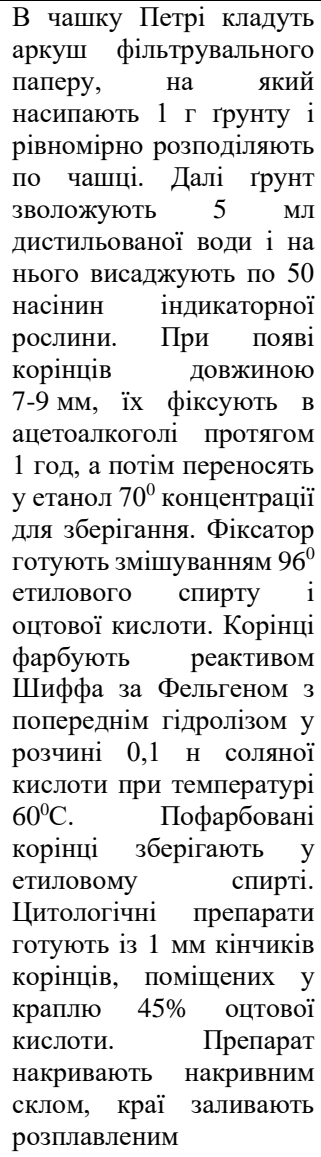 & 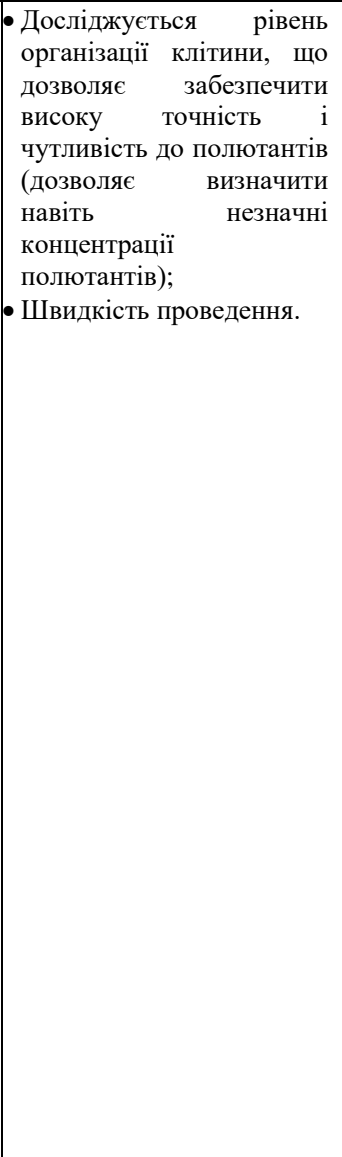 & $\begin{array}{l}\text { - Потреба у спеціально } \\
\text { навчених } \\
\text { спеціалістах; } \\
\text { - Необхідність } \\
\text { лабораторії } \\
\text { обладнання; } \\
\text { - Матеріальні } \\
\text { витрати. }\end{array}$ \\
\hline
\end{tabular}


Продовження таблиці 2

\begin{tabular}{|c|c|c|c|c|}
\hline 1 & 2 & 3 & 4 & 5 \\
\hline & & 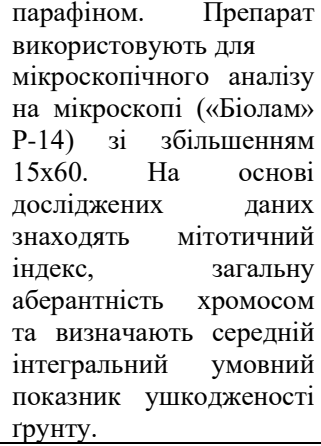 & & \\
\hline $\begin{array}{l}\text { Діагностика } \\
\text { грунтів за } \\
\text { фермента- } \\
\text { тивною } \\
\text { активністю } \\
\text { (за } \\
\text { методичними } \\
\text { розробками } \\
\text { Лисак Л.В.) }\end{array}$ & \begin{tabular}{|l} 
Поза- \\
клітинний
\end{tabular} & 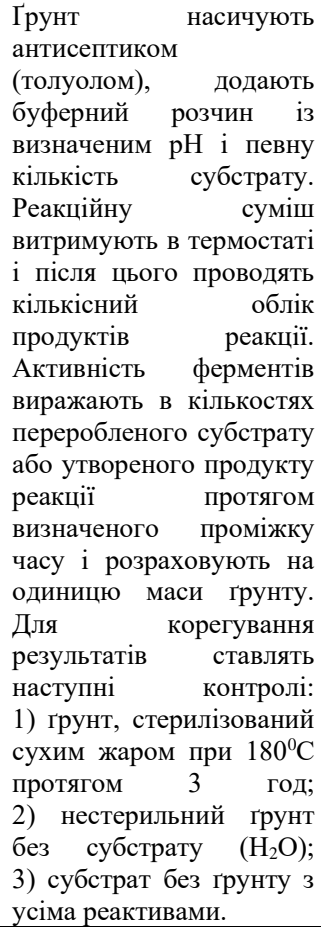 & $\begin{array}{ll}\text { - Дослідження } & \text { активності } \\
\text { грунтових } & \text { ферментів } \\
\text { відображає проходження } \\
\text { біохімічних процесів у } \\
\text { едафотопі та є одним із } \\
\text { інтегральних показників } \\
\text { його } & \text { біотичної } \\
\text { активності. } & \end{array}$ & $\begin{array}{ll}\text { - Потреба } & \text { у } \\
\text { кваліфікованих } & \\
\text { спеціалістах; } & \\
\text { - Необхідність } & \\
\text { лабораторії } & \text { та } \\
\text { обладнання; } & \\
\text { - Матеріальні затрати. }\end{array}$ \\
\hline
\end{tabular}

Джерела: [13-19].

Проведений аналіз наведених методик мікробіологічного дослідження стану грунтів свідчить про те, що найбільш доступним методом є ростовий тест, який дає змогу відносно швидко та без особливих грошових витрат визначити фітотоксичний ефект грунту. Це $є$ великою перевагою, що дає змогу систематичного проведення моніторингу стану грунтів, уражених внаслідок пожежогасіння піноутворюючими розчинами.

3 іншого боку, найбільш точним методом є тест «Аберантність хромосом», який проводиться на клітинному рівні, що дозволяе забезпечити високу точність і визначити навіть незначні перевищення концентрацій полютантів. Це $є$ дуже важливою характеристикою при дослідженнях впливу розчинів піноутворювачів для гасіння пожеж на грунти, оскільки зазвичай території виникнення пожеж використовуються населенням для ведення господарської діяльності. 
Враховуючи вищенаведене, для оцінки токсичності грунтів, забруднених розчинами піноутворювачів для гасіння пожеж, запропоновано використовувати ростовий тест в комплексі 3 тестом «Аберантність хромосом». При цьому, для отримання більш точної і об'єктивної оцінки, варто застосовувати декілька різних тест-об'єктів. Запропонований комплексний підхід дасть змогу визначати мікробіологічний стан грунтів, ступінь токсичного впливу на родючість грунтів, прилеглих до територій, що піддавалися забрудненню хімічними компонентами в складі розчинів для пожежогасіння, та ступінь впливу даних забрудників на мезофауну грунтів.

\section{Висновки та пропозиції}

Визначено, що для отримання найбільш повної та об'єктивної інформації про мікробіологічний стан грунтів, забруднених розчинами піноутворювачів для гасіння пожеж, слід застосовувати комплекс біоіндикаційних методів оцінки шкідливості, який повинен включати ростовий тест та тест «Аберантність хромосом», при цьому обов'язковим $\epsilon$ використання комплексу тесторганізмів, найбільш чутливих до хімічного складу досліджуваного розчину для пожежогасіння.

\section{СПИСОК ЛІТРАТУРИ}

1. Український науково-дослідний інститут цивільного захисту (УкрНДІЦЗ). Статистика пожеж, 2019. URL: https://undicz.dsns.gov.ua/ua/STATISTIKAPOZHEZH.html.

2. Лісняк А.А., Тригуб В.В., Сенчихін Ю.М., Сировой В.В. Звіт про науково-дослідну роботу написання та підготовка до друку навчального посібника "Пожежна тактика", 2016. URL: https://www.dsns.gov.ua/files/2017/4/25/zvit_osvita_i_nauka/7_Пожежна\%20 тактика.pdf.

3. Боровиков В. Проблемні питання застосування піноутворювачів для гасіння пожеж. Бизнес и безопасность. 2003. №4. С. 75-78.

4. Громовик А.И. Современные инструментальные методы в почвоведении. Теория и практика. Воронеж, 2010. 60 с.

5. Васенко О.Г., Рибалова О.В., Артем'єв С.Р., Горбань Н.С., Коробкова Г.В., Полозенцєва В.О., Козловська О.В., Мацак А.О., Савічєв А.А. Інтегральні та комплексні оцінки стану навколишнього природного середовища: монографія. Харків, $2015.419 \mathrm{c}$.

6. Мороз О.А. Фізико-хімічні методи аналізу грунтів. Студентський вісник Національного університету водного господарства та природокористування. 2015. №2. C. 54-57.

7. Горова А. Оцінка токсичності грунтів Червоноградського гірничопромислового району за допомогою ростового тесту. Вісник Львівського університету. 2008. №48. C. $189-194$.

8. Миленька М.М. Біоіндикаційна оцінка екологічного стану Бурштинської урбоекосистеми : автореф. дис. на здобуття наук. ступеня канд. біол. наук : 03.00.16, Дніпропетровськ, 2009. 16 с.

9. Бубнов А.Г., Буймова С.А., Гущин А.А., Извекова Т.В. Биотестовый анализ интегральный метод оценки качества объектов окружающей среды. Иваново, 2007. $112 \mathrm{c}$.

10. Азарова С.В. Опыт применения методов биотестирования для оценки токсичности отходов горнодобывающих предприятий. IX Международная биогеохимическая школа. 2011. С. 36-39. 
11. Мазницька В.О., Труш В. Є., Новохатько О. В., Красковська М. А. Біотестування гірничої маси з відвалів Малокохнівського кар'єру. Наукові технологї. 2013. №1. C. $127-130$.

12. Азарова С.В. Отходы предприятий и комплексная оценка их опасности для окружающей среды (на примере объектов республики Хакасия) : автореф. дис. на здобуття наук. ступеня канд. геол.-мін. наук : 25.00.36, Томск, 2005. 21 с.

13. Бешлей 3.М., Бешлей С. В., Баранов В. І., Терек О. І. Використання рослинних тестсистем для оцінки токсичності техногенно забруднених субстратів. Вісник Харківського національного аграрного університету. 2014. №1. С. 97-102.

14. Губачов О.І. Особливості використання рослин для біотестування грунтів з метою визначення рівня екологічної безпеки промислових територій. Науковий вісник КУЕITУ. 2010. С. 164-171.

15. Гонгальский К.Б. Почвенные безпозвоночные как биоиндикаторы промышленного воздействия в лесных экосистемах центра европейской России : автореф. дис. на здобуття наук. ступеня канд. біол. наук :03.00.16, Москва, 2004.18 с.

16. Пінчук М.О. Дослідження грунту. Начіональний еколого-натуралістичний иентр учнівської молоді. 2018. С. 32.

17. Горова А.І., Риженко С.А., Скворцова Т.В. Методичні рекомендації «Обстеження та районування території за ступенем впливу антропогенних чинників на стан об’єктів довкілля з використанням цитогенетичних методів». Донецьк, 2007. 25 с.

18. Мелехова О.П., Егорова Е.И., Евсеева Т.И. Биологический контроль окружающей среды: биоиндикация и биотестирование. Москва, 2007. 288 с.

19. Левик В.I. Ферментативна активність грунтів техногенних територій Немирівського родовища сірки. Збірник наукових праџь Харківського національного педагогічного університету імені Г.С. Сковороди. 2009. №11. С. 131-136.

Стаття надійшла до редакиії 23.01.2020 і прийнята до друку після рецензування 02.04.2020

\section{REFERENCES}

1. Ukrainian Civil Protection Research Institute (2019). Statystyka pozhezh. Retrieved from https://undicz.dsns.gov.ua/ua/STATISTIKA-POZHEZH.html.

2. Lisniak, A.A., Tryhub, V.V., Senchykhin, Yu.M., \& Syrovoi, V.V. (2016). Zvit pro naukovo-doslidnu robotu napysannia ta pidhotovka do druku navchalnoho posibnyka "Pozhezhna taktyka". Retrieved from https://www.dsns.gov.ua/files/2017/4/25/zvit_ osvita_i_nauka/7_Пожежна\%20тактика.pdf.

3. Borovykov, V. (2003). Problemni pytannia zastosuvannia pinoutvoriuvachiv dlia hasinnia pozhezh. [Problematic issues of application of foaming agents for fire fighting]. Byznes y bezopasnost, 4, 75-78.

4. Hromovyk, A.Y. (2010). Sovremennie instrumentalnie metody v pochvovedenyy. Teoryia y praktyka. [Modern instrumental methods in soil science. Theory and practice]. Voronezh. 5. Vasenko, O.H., Rybalova, O.V., Artemiev, S.R., Horban, N.S., Korobkova, H.V., Polozentsieva, V.O., Kozlovska, O.V., Matsak, A.O., \& Savichiev, A.A. (2015). Intehralni ta kompleksni otsinky stanu navkolyshnoho pryrodnoho seredovyshcha: monohrafiia. [Integral and complex environmental assessments: a monograph]. Kharkiv.

6. Moroz, O.A. (2015). Fizyko-khimichni metody analizu hruntiv. [Physico-chemical methods of soil analysis]. Studentskyi visnyk Natsionalnoho universytetu vodnoho hospodarstva ta pryrodokorystuvannia, 1, 54-57.

7. Horova, A. (2008). Otsinka toksychnosti hruntiv Chervonohradskoho hirnychopromyslovoho raionu za dopomohoiu rostovoho testu. [Soil toxicity assessment of Chervonohrad mining district with the help of growth test.] Visnyk Lvivskoho universytetu, 48, 189-194. 
8. Mylenka, M.M. (2009). Bioindykatsiina otsinka ekolohichnoho stanu Burshtynskoi urboekosystemy. [Bio-indication estimation of Burshtyn urban ecosystem]. Extended abstract of candidate's thesis. Dnipropetrovsk.

9. Bubnov, A.H., Buimova, S.A., Hushchyn, A.A., \& Yzvekova, T.V. (2007). Byotestovi analyz - intehralnyi metod otsenky kachestva obektov okruzhaiushchei sredy. [Biotest analysis is an integral method of assessing the quality of environmental objects ]. Ivanovo.

10. Azarova, S.V. (2011). Opyt prymenenyia metodov byotestyrovanyia dlia otsenky toksychnosty otkhodov hornodobyvaiushchykh predpryiatyi. [Experience in applying biotesting methods to assess waste toxicity of mining enterprises]. In IX Mezhdunarodnaia byoheokhymycheskaia shkola. p. 36-39.

11. Maznytska, V.O., Trush, V.Ye., Novokhatko, O.V., \& Kraskovska, M.A. (2013). Biotestuvannia hirnychoi masy z vidvaliv Malokokhnivskoho karieru [Biotesting of rock mass from the piles of the Malokokhnivskyi quarry]. Naukovi tekhnolohii, 1, 127-130.

12. Azarova, S.V. (2005). Otkhody predpryiatyi y kompleksnaia otsenka ih opasnosty dlia okruzhaiushchei sredy ( na prymere obiektov respublyky Khakasyia). [Waste of enterprises and complex assessment of their danger to the environment (on the example of objects of the Republic of Khakassia]. Extended abstract of candidate's thesis. Tomsk.

13. Beshlei, Z.M., Beshlei, S.V., Baranov, V.I., \& Terek, O.I. (2014). Vykorystannia roslynnykh test-system dlia otsinky toksychnosti tekhnohenno zabrudnenykh substrativ. [The use of plant test systems to evaluate the toxicity of technogenically contaminated substrates]. Visnyk Kharkivskoho natsionalnoho ahrarnoho universytetu, 1, 97-102.

14. Hubachov, O.I. (2010). Osoblyvosti vykorystannia roslyn dlia biotestuvannia hruntiv z metoiu vyznachennia rivnia ekolohichnoi bezpeky promyslovykh terytorii. [Features of using plants for soil biotesting to determine the level of environmental safety of industrial areas]. Naukovyi visnyk KUEITU, 164-171.

15. Honhalskyi, K.B. (2004). Pochvennye bezpozvonochnye kak byoyndykatori promishlennoho vozdeistvyia $\mathrm{v}$ lesnykh ekosystemakh tsentra evropeiskoi Rossyy. [Soil invertebrates as bioindicators of industrial impact in forest ecosystems of the center of European Russia]. Extended abstract of candidate's thesis. Moskva.

16. Pinchuk, M.O. (2018). Doslidzhennia hruntu. [Soil research]. Natsionalnyi ekolohonaturalistychnyi tsentr uchnivskoi molodi, p. 32.

17. Horova, A.I., Ryzhenko, S.A., \& Skvortsova, T.V. (2007). Metodychni rekomendatsii "Obstezhennia ta raionuvannia terytorii za stupenem vplyvu antropohennykh chynnykiv na stan obiektiv dovkillia z vykorystanniam tsytohenetychnykh metodiv». [Methodological recommendations "Survey and zoning of the territory by the degree of influence of anthropogenic factors on the state of environmental objects using cytogenetic methods"]. Donetsk.

18. Melekhova, O.P., Ehorova, E.Y., \& Evseeva, T.Y. (2007). Byolohycheskyi kontrol okruzhaiuchei sredy: byoyndykatsyia y byotestyrovanye. [Biological control of the environment: bioindication and biotesting]. Moskva.

19. Levyk, V.I. (2009). Fermentatyvna aktyvnist hruntiv tekhnohennykh terytorii Nemyrivskoho rodovyshcha sirky. [Enzymatic activity of soils of the technogenic territories of the Nemyriv sulfur field]. Zbirnyk nakovykh prats Kharkivskoho natsionalnoho pedahohichnoho universytetu imeni H.S. Skovorody, 11, 131-136.

The article was received 23.01.2020 and was accepted after revision 02.04.2020

\section{Порошенко Сергій Сергійович}

Студент 6-го курсу, ЕКм-613, Львівський державний університет безпеки життедіяльності

Адреса робоча: 79007, м. Львів, вул. Клепарівська, 35

e-mail: ldubzh.lviv@dsns.gov.ua 